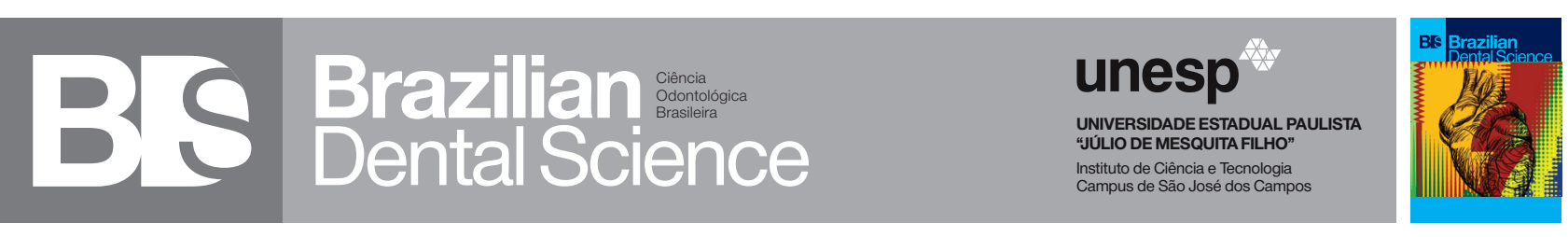

\title{
Evaluation of dimensional stability and details reproduction of alginate molds storage in different times and temperature
}

Avaliação da estabilidade dimensional e reprodução de detalhes de moldes de alginatos armazenados por diferentes tempos e temperatura

Rafael da Rocha Santos PENFOLD ${ }^{1}$, William Cunha BRANDT ${ }^{2}$, Milton Edson MIRANDA ${ }^{1}$ Rafael Pino VITTI $^{3}$
1 - Department of Prosthodontics - School of Dentistry - São Leopoldo Mandic - Campinas - SP - Brazil.
2 - Department of Implantology - School of Dentistry - University of Santo Amaro - São Paulo - SP - Brazil.
3 - Department of Prosthodontics - School of Dentistry - University of Taubaté - Taubaté - SP - Brazil.

\section{ABSTRACT}

Objective: The aim of this study was to evaluate dimensional stability and detail reproduction in alginate molds stored at different times and temperatures. Material and Methods: Three different commercially available alginates (Cavex Color Change, Jeltrate Plus and Hydrogum 5) were tested at four different times (0 control, 1,3 and 5 days) and two temperatures $\left(25^{\circ} \mathrm{C}\right.$ and $\left.37^{\circ} \mathrm{C}\right)(\mathrm{n}=5)$. The alginates were handled following the manufacturer's instructions. The impression procedures occurred in an environment with controlled room temperature $\left(25^{\circ} \mathrm{C}\right)$ and relative humidity $(50 \pm 5 \%)$. A metallic model (ISO 1563:1990) was used to perform the impressions. The tray containing alginate remained on the metallic model under constant pressure (2 kgf) until the alginate gelation process. The molds were stored (different times and temperatures) and analyzed in stereomicroscope at 30x magnification and $0.5 \mu \mathrm{m}$ accuracy (Olympus Measuring Microscope STM). The molds and the metallic model measurements were compared, and the data were statistically analyzed by Kolmogorov-Smirnov and three-way ANOVA tests, and the means were compared by Tukey test (5\%). Results: The results showed no double interactions ( $p>0.05$ ) and the different alginates presented statistically similar values of dimensional stability $(\mathrm{p}=0.102)$. However, $25^{\circ} \mathrm{C}$ (temperature) and control group (time) showed the highest values of dimensional stability $(\mathrm{p}<0.05)$. Jeltrate Plus was the only material that presented inaccuracy in details reproduction. Conclusion: It is recommended that, for tested alginates, the stone casts should be poured immediately, even though the molds are dimensionally stable up to 5 days when stored at $25^{\circ} \mathrm{C}$.

\section{KEYWORDS}

Dental impression materials; Dimensional measurement accuracy; Shrinkage.

\section{RESUMO}

Objetivo: O objetivo neste estudo foi avaliar a estabilidade dimensional e a reprodução de detalhes em moldes de alginatos armazenados em diferentes tempos e temperaturas. Material e Métodos: Foram testadas três diferentes marcas de alginato (Cavex ColorChange, Jeltrate Plus e Hydrogum 5), sendo que esses materiais foram armazenados por quatro diferentes tempos ( 0 - controle, 1,3 e 5 dias) e duas diferentes temperaturas $\left(25^{\circ} \mathrm{C}\right.$ e $\left.37^{\circ} \mathrm{C}\right)(n=5)$. Os alginatos foram manipulados seguindo as instruções do fabricante. A moldagem ocorreu em um ambiente com temperatura $\left(25^{\circ} \mathrm{C}\right)$ e umidade relativa $(50 \pm 5 \%)$ controladas. Foi utilizado um modelo metálico (ISO 1563:1990) para a realização das moldagens. A moldeira contendo o alginato permaneceu sobre o modelo metálico sob pressão constante de 2 kgf até a geleificação do material. Em seguida, os moldes foram armazenados nos tempos e temperaturas testados, sendo posteriormente avaliados sob um microscópio comparador (Olympus Measuring Microscope STM) com precisão de 0,5 $\mu \mathrm{m}$. As medidas dos moldes de alginato foram comparadas com as medidas do modelo metálico padrão, sendo os dados analisados estatisticamente pelos testes de Kolmogorov-Smirnov e ANOVA três fatores, sendo as médias foram comparadas pelo teste de Tukey (5\%). Resultados: Os resultados mostraram nenhuma interação dupla ( $p>0,05)$, sendo que os diferentes alginatos apresentaram valores de estabilidade dimensional estatisticamente semelhantes entre si $(\mathrm{p}=0,102)$. Já a temperatura de $25^{\circ} \mathrm{C}$ e o grupo controle (tempo) mostraram os maiores valores de estabilidade dimensional $(\mathrm{p}<0,05)$. $\mathrm{O}$ Jeltrate Plus foi o único material que apresentou imprecisão na reprodução de detalhes. Conclusão: Recomenda-se que os alginatos testados tenham os modelos de gesso vazados imediatamente, apesar dos moldes serem dimensionalmente estáveis até 5 dias desde que armazenados a $25^{\circ} \mathrm{C}$.

\section{PALAVRAS-CHAVE}

Materiais de moldagem dentários; Medição da precisão dimensional; Contração. 


\section{INTRODUCTION}

A lginates are impression materials commonly used in dental practices because of their low cost, easy handling, hydrophilic, pleasant taste and odor [1]. They are used as initial impression material for prosthetic and/or orthodontic planning, diagnosis of malocclusion, preparation of surgical guides, provisional prostheses, individual and bleaching trays [2]. Alginates are commercially available in powder, and their gelation process occurs by mixing it with water. The powder contains sodium or potassium alginate (soluble alginates), diatomaceous earth and zinc oxide (fillers), calcium sulfate (activator), fluorides, such as potassium fluoride and titanium (accelerator) and sodium phosphate (retarder) [1,3]. After gelation, the gel forms a lattice structure, which retains unreacted sodium alginate with calcium salt, the excess water (by-product) and filler particles [1]. Under these conditions the final alginate structure is very sensitive to the conditions that can alter the amount of water in the fibrillar structure. .

Consequently, the dimensional stability of an alginate mold is highly vulnerable, especially to changes in temperature and humidity during storage $[4,8]$. Such factors may cause mold expansion by imbibition (water sorption) or shrinkage of the mold due to syneresis/ evaporation (water loss) [1], compromising dimensional stability and detail reproduction $[4,8]$. A mold must be dimensionally stable and have high details reproduction for the restorative treatment has clinically successful [1]. Alginate molds should be filled immediately with dental stone to minimize the dimensional changes which occurs in the mold over time [1,2]. Due to a series of common setbacks in the dental office, such as amount of patients and disinfection procedures of the molds, it is not always possible to pour a mold with dental stone immediately to minimize such distortions $[3,5]$.
In this way, it would be ideal that the alginate molds presented adequate dimensional stability even with the extended-pour of the stone casts. Extended-storage alginates have become commercially available and the mold could be stored for up to 5 days $[2,4,6,8-10]$. However, there is still not a consensus in the scientific literature whether these molds can be stored for a period of 5 days without any problem in dimensional stability or details reproduction, according to the International Organization for Standardization (ISO 1563:1990) [11].

The aim of this study was to evaluate the effects of time and temperature of storage of alginate molds on dimensional stability and details reproduction. The null hypotheses were that there would be no difference in dimensional stability between the different (1) alginates, (2) times and (3) mold storage temperatures.

\section{MATERIAL \& METHODS}

Molds were prepared from different alginates, being stored in different times and temperature, in order to evaluate the dimensional stability and detail reproduction. The following alginates were used: Cavex ColorChange (Cavex Holland BV, Haarlem, The Netherlands), Hydrogum 5 (Zhermack, Badia Polesine, RO, Italy) and Jeltrate Plus (Dentsply Indústria e Comércio Ltda., Rio de Janeiro, RJ, Brazil) (Table 1). The materials were handled according to the manufacturers' instructions. The powder and liquid were measured in an analytical balance with $0.1 \mathrm{mg}$ of precision (Mark M214A, Bel Engineering, Monza, MI, Italy) and graduated test tube, respectively. Each alginate tested was divided into 8 groups $(n=5)$ according to the times (0 - control, 1, 3 and 5 days) and storage temperatures $\left(25^{\circ} \mathrm{C}\right.$ and $37^{\circ} \mathrm{C}$ ).

The alginate molds were prepared on a stainless steel matrix (38 mm external diameter and $30 \mathrm{~mm}$ internal diameter) containing three horizontal lines (20, 50 and $75 \mu \mathrm{m}$ wide) 
parallel to each other, $25 \mathrm{~mm}$ long and $2.5 \mathrm{~mm}$ between the lines. In the matrix there were also two vertical lines crossing the horizontal lines to mark the measuring points of the distances. Previously to the impression procedure, the matrix was cleaned in an ultrasonic bath with distilled water and dried with compressed air. A stainless steel tray (31 mm internal diameter and $5 \mathrm{~mm}$ height) was used for carrying the impression material (Figure 1). The tray was placed on the matrix and a pressure of $2 \mathrm{kgf}$ was applied by pneumatic press machine to simulate the impression procedure and allow the excess material to overflow (ISO 1563:1990). The impression procedures were performed in a room with controlled temperature $\left(25^{\circ} \mathrm{C}\right)$ and humidity $(50 \pm 5 \%)$. The molds were removed after alginate gelation (Figure 2). Samples were stored in closed containers with $100 \%$ relative humidity at $25^{\circ} \mathrm{C}$ and at $37^{\circ} \mathrm{C}$ for the previously described periods of time.

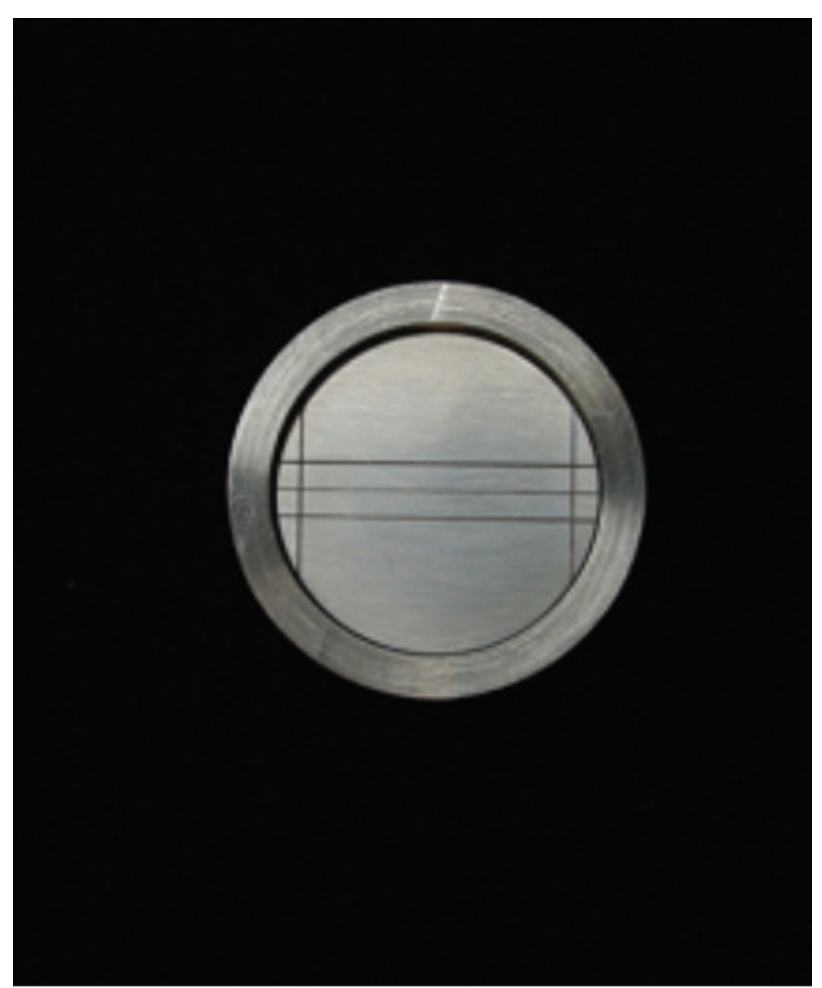

Figure 1 - Stainless steel matrix and tray used.

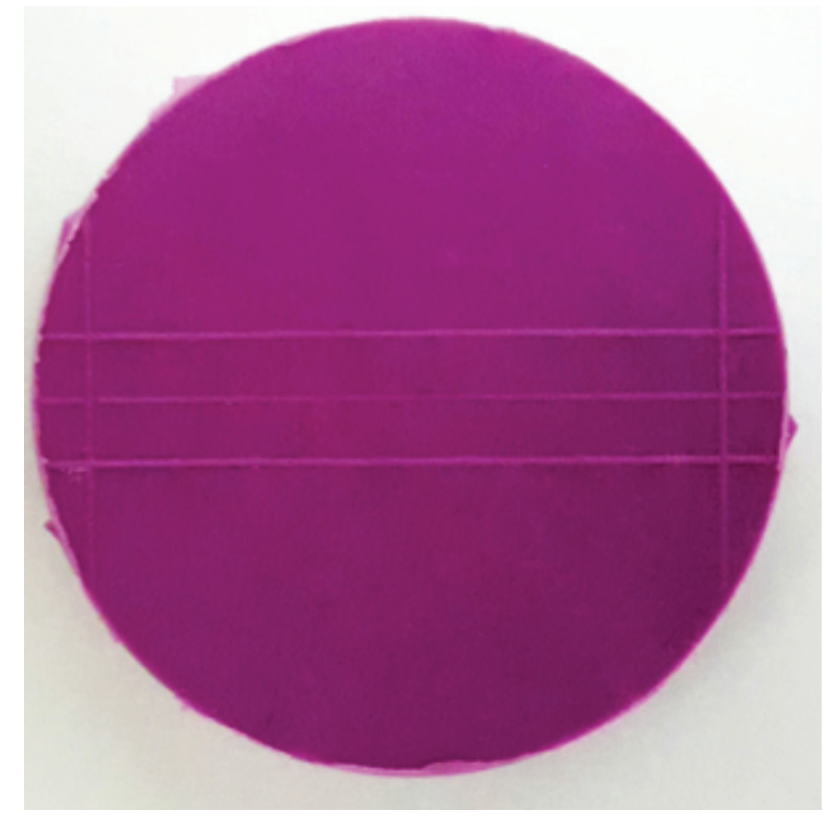

Figure 2 - Molds used for distances measurements.

Table 1 - Brand name, manufacturer, and composition of the different alginates evaluated

\begin{tabular}{|c|c|c|}
\hline Brand name & Manufacturer & Composition \\
\hline $\begin{array}{l}\text { Cavex Color- } \\
\text { Change }\end{array}$ & $\begin{array}{c}\text { Cavex Holland } \\
\text { BV }\end{array}$ & $\begin{array}{l}\text { Alginate, calcium sulfate, filler, } \\
\text { retarder, stabilisers, flavour and } \\
\text { colour indicators. }\end{array}$ \\
\hline Hydrogum 5 & Zhermack & $\begin{array}{l}\text { Potassium alginate, diatomaceous } \\
\text { earth, calcium sulfate, trisodium phos- } \\
\text { phate and triaminofunctional silane. }\end{array}$ \\
\hline Jeltrate Plus & Dentsply & $\begin{array}{c}\text { Potassium alginate, calcium sulfate, } \\
\text { crystalline silica, amorphous silica, } \\
\text { tetrasodium pyrophosphate, magne- } \\
\text { sium oxide, quaternary ammonium } \\
\text { compound, aspartame, organic glycol, } \\
\text { yellow iron oxide.* }\end{array}$ \\
\hline
\end{tabular}

*manufacturer. †Rodrigues et al. [18]

The dimensional stability and detail reproduction values were evaluated using a measuring microscope STM (Olympus Optical Co., Japan) with a 30x magnification and accuracy up to $0.5 \mu \mathrm{m}$. Each ocular lens of the microscope had four dashed lines with a central intersection. This center point was used to mark the beginning and end of the line length reading (L). The dimensional stability was calculated 
according to the ISO $1563: 1990$ using the equation: $\mathrm{L}=[(\mathrm{L} 2-\mathrm{L} 1) / \mathrm{L} 1] \times 100$ where L1 is the distance between the lines of the matrix and L2 is the distance between the lines in the samples (molds). During the reading procedure the room temperature was maintained at $25^{\circ} \mathrm{C}$.

The dimensional change values were converted into percent. The data were submitted to Kolmogorov-Smirnov test (normality) and analysis of variance (ANOVA three-way). The means were compared by Tukey $(\alpha=0.05)$.

\section{RESULTS}

Data did not show statistically significant differences for the interaction between two factors alginate $x$ time $(p=0.366)$, alginate $x$ temperature $(p=0.090)$ and time $x$ temperature $(p=0.421)$, or for the interaction among all three study factors (alginate $\mathrm{x}$ time $\mathrm{x}$ temperature; $\mathrm{p}=0.634$ ). The alginate brands also showed no statistically significant differences $(p=0.102)$. Thus, all alginates tested presented similar dimensional stability values.

ANOVA indicated significant differences for the isolated factors time $(\mathrm{p}<0.05)$ and temperature $(\mathrm{p}<0.05)$. The Tukey test showed that the control group presented statistically the highest dimensional stability values (Table 2 ). Table 3 shows that the storage temperature of $37^{\circ} \mathrm{C}$ had statistically the lowest values of dimensional stability.

Table 2 - Means (SD) of dimensional stability (\%) of different times

\begin{tabular}{|cc|}
\hline Time & Dimensional Stability \\
\hline 0 (control) & $98.98(0.73) \mathrm{A}$ \\
\hline 1 day & $95.77(0.94) \mathrm{B}$ \\
\hline 3 days & $95.90(1.05) \mathrm{B}$ \\
\hline 5 days & $95.06(1.28) \mathrm{B}$ \\
\hline
\end{tabular}

Data with different letters are statistically different $(p<0.05)$.
Figure 3 shows the percentage of details reproduction of each alginate tested. All specimens reproduced the $75 \mu \mathrm{m}$ line (100\%). Hydrogum 5 was the alginate that was able to reproduce the largest number of $50 \mu \mathrm{m}$ lines (>20\%). On other hand, Jeltrate Plus reproduced the $25 \mu \mathrm{m}$ line more frequently than Hydrogum 5 (2.5\%).

Table 3 - Means (SD) of dimensional stability (\%) of different temperatures

\begin{tabular}{|c|c|}
\hline Temperature & Dimensional Stability \\
\hline $25^{\circ} \mathrm{C}$ & $98.86(0.55) \mathrm{A}$ \\
\hline $37^{\circ} \mathrm{C}$ & $95.33(0.90) \mathrm{B}$ \\
\hline
\end{tabular}

Data with different letters are statistically different $(p<0.05)$.

Table 4 - Details reproduction (\%) of the alginates tested

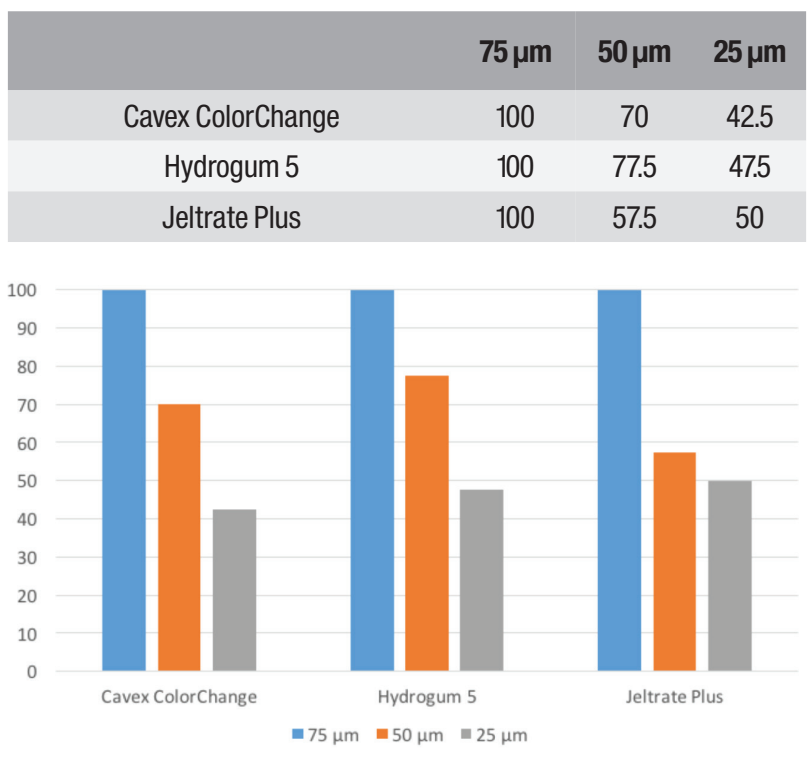

Figure 3 - Details reproduction (\%) of the alginates tested.

\section{DISCUSSION}

Based on the results of the present study, the first null hypothesis was accepted since there was no difference between the alginates tested. However, second and third null hypothesis were rejected, since differences in dimensional stability between the different storage times and 
temperatures were observed.

Despite the different chemical components present in the composition of the evaluated alginates (Table 1), and possibly the alginate/ filler ratio, these discrepancies were not able to promote statistically significant differences in the dimensional stability. In addition, all the alginates presented dimensional stability averages (Cavex ColorChange, 96.40\%; Hydrogum 5, 97.07\%; and Jeltrate Plus 96.91\%) within the value recommended by ISO 1563:1990 (95\% of elastic recovery). The dimensional stability values of this study are below $100 \%$. This indicates that the molds suffered shrinkage. Even controlling the humidity during the impression and storing procedures of the molds to minimize the effects of syneresis, evaporation and soaking, there is the shrinkage of the material inherent to its gelation process [1,12-14]. The expansion of gypsum used in stone casts compensates or even extrapolates the shrinkage of alginates [8]. It would be interesting for future studies to verify the dimensional stability in stone casts, since it would represent a real clinical situation.

Another limitation of the present study is that in order to verify the influence of each study factor there is a control of other variables that influence the quality of the molds, such as pressure applied during molding, removal of the tray in single movement avoiding tilting movements, standardization of the temperature throughout the impression procedure, minimizing thermal changes occurring between buccal and room temperature, and throughout the mold storage [4-6,8,15]. Routinely these dimensional stability values for alginates could be different from the results of this study, since it is impossible to control all of these variables.

On the other hand, the different storage times promoted differences in dimensional stability (Table 2), and the control group, where the distances were immediately measured, presented the lowest dimensional instability, corroborating with other studies [8,16-19].
The other evaluated storage times (1, 3 and 5 days) were similar to each other, however, they presented lower values of dimensional stability when compared to the control group.These values are in agreement with ISO 1563:1990 (95\%), indicating that the molds made from alginates evaluated may be stored for up to 5 days. The manufacturers of these alginates recommend that the molds can be stored for up to 4 days (Jeltrate Plus), 5 days (Hydrogum 5) and 9 days (Cavex ColorChange), maintaining the relative humidity at $100 \%$. Despite of 5 day storage provided a satisfactory mean of dimensional stability (96.91\%), the molds of Jeltrate Plus storage for more time than recommended by manufacturer affected negatively the details reproduction values (54.5\%) (Figure 3).

The different temperatures $\left(25^{\circ} \mathrm{C}\right.$ and $37^{\circ} \mathrm{C}$ ) also presented different dimensional stability means, and the best values were found for the molds stored at $25^{\circ} \mathrm{C}$ (Table 3). Although there were differences between the two groups, both presented dimensional stability within the value recommended by ISO 1563:1990 (95\%). The best dimensional stability for the molds stored at $25^{\circ} \mathrm{C}$ may be explained by the absence of thermal change between the impression, storage and measuring of the samples [4-6,8] since all these procedures were performed at $25^{\circ} \mathrm{C}$. The temperature difference provides thermal shrinkage in the impression material $[1,6,9]$. It is speculated that clinically these results would be reversed, since the buccal cavity temperature is $\sim 37^{\circ} \mathrm{C}$ and therefore the storage of the molds at that temperature would prevent or minimize the thermal shrinkage of the alginate.

Only small differences are observed between the alginates in the $25 \mu \mathrm{m}$ line (Table 4). In the $50 \mu \mathrm{m}$ line there was a larger difference (>10\%), where Jeltrate Plus alginate presented the lowest values of details reproduction. It is important to emphasize that ISO $1563: 1990$ guideline recommends that at least $66 \%$ of 
the samples should perfectly reproduce the $50 \mu \mathrm{m}$ line without any interruption. With the exception of Jeltrate Plus (54.5\%), all other alginates showed higher detail values than those established by ISO 1563:1990. Since alginate is not a high-precision impression material (like elastomers) the $25 \mu \mathrm{m}$ line is disregarded in this evaluation. However, the quality of details reproduction is important in dental practice, since alginate is the impression material used for several initial prosthetic, orthodontic and restorative procedures. Any imprecision in this step could compromise the whole rehabilitation treatment, interfering with the prognosis of the clinical treatment $[15,20,21]$.

In this study, it was performed a methodology to simulate a clinical situation, where the immediate pouring of an impression may not always be possible, as well as the presence of thermal changes (buccal cavity $\mathrm{x}$ environment) during impression and storage procedures $[4,6]$. Some studies evaluate the effect of temperature on the storage of alginate molds $[4,6,8]$. However, there is a lack of standardization in temperature values. Thus, it is difficult to compare the results of this study with other studies. Despite the lack of standardization in the storage temperatures of the molds, there is a consensus that thermal change is a relevant factor in the evaluation of the dimensional stability of impression materials $[1,4,5,8-10,20]$.

\section{CONCLUSION}

All alginates tested can be stored for up to 5 days in $100 \%$ relative humidity, with the exception of Jeltrate Plus, which presented inaccuracy in details reproduction. The storage of the alginate mold must be performed at the same temperature of the impression procedure.

\section{REFERENCES}

1. OAnusavice KJ, editor. Phillips' science of dental materials. 12 ed. St. Louis: Saunders C0;2013.
2. Sedda M, Casarotto A, Raustia A, Borracchini A. Effect of storage time on the accuracy of casts made from different irreversible hydrocolloids. J Contemp DentPract.2008 May;9(4):59-66.

3. Carlo HL, Fonseca RB, Goncalves LS, Correr-Sobrinho L, Soares CJ, Sinhoreti MA. Analysis of filler particle levels and sizes in dental alginates. Mater Res. 2010 Apr-June;13(2):261-4.

4. Todd JA, Oesterle LJ, Newman SM, Shellhart WC. Dimensional changes of extended-pour alginate impression materials. Am J Orthod Dentofacial Orthop. 2013 Apr;143(4 Suppl):S55-63. doi: 10.1016/jajodo.2012.06.016.

5. Wadhwa SS, Mehta R, Duggal N, Vasudeva K. The effect of pouring time on the dimensional accuracy of casts made from different irreversible hydrocolloid impression materials. Contemp Clin Dent. 2013 Jul;:4(3):313-8.

6. Rohanian A,ShabestariGO,Zeighami S, Samadi MJ, Shamshiri AR. Effect of storage time of extended-pour and conventional alginate impressions on dimensional accuracy of casts. J Dent (Tehran). 2014 Nov;1(6):655-64.

7. Aalaei S, Gani-Khanloo R, Gholami F.Effect of storage period on dimensional stability of Alginplus and Hydrogum 5.J Dent (Tehran). 2017 Jan;14(1):31-9.

8. Guiraldo RD, Moreti AF, Martinelli J, Berger SB, Meneghel LL, Caixeta RV, Sinhoreti MA. Influence of alginate impression materials and storage time on surface detail reproduction and dimensional accuracy of stone models. Acta Odontol Latinoam. 2015;28(2):156-61.

9. Walker MP,Burckhard J, Mitts DA, Williams KB. Dimensional change over time of extended-storage alginate impression materials. Angle Orthod. 2010 Nov;80(6):1110-5.

10. Gümüş HO, Dinçel M, Büyük SK, Kllnnc HI, Bilgin MS, Zortuk M. The effect of pouring time on the dimensional stability of casts made from conventional and extended-pour irreversible hydrocolloids by 3D modelling. J Dent Sci. 2015 Sep;10(3):275-81.

11. International Organization for Standardization. Dental alginate impression material. $N^{\circ} 1563: 1990$.

12. Alcan T,Ceylanoglu C,Baysal B. The relationship between digital model accuracy and time-dependent deformation of alginate impressions. Angle Orthod. 2009 Jan;79(1):30-6.

13. Fellows $\mathrm{CM}$, Thomas GA. Determination of bound and unbound water in dental alginate irreversible hydrocolloid by nuclear magnetic resonance spectroscopy. Dent Mater.2009 Apr;25(4):486-93.

14. Hiraguchi H, Kaketani M, Hirose H, Yoneyama T. The influence of storing alginate impressions sprayed with disinfectant on dimensional accuracy and deformation of maxillary edentulous stone models. Dent Mater J. 2010 May;29(3):309-15.

15. Vitti RP,Feitosa VP,Bacchi A, Brandt WC, Miranda ME, Sinhoreti MAC. Dimensional accuracy of different impression techniques of partially edentulous mandibular arch. Rev Gaúch Odontol. 2017 Jan-Mar;65(1):25-9.

16. Imbery TA, Nehring J, Janus C, Moon PC. Accuracy and dimensional stability of extended-pour and conventional alginate impression materials. J Am Dent Assoc. 2010 Jan;141(1):32-9.

17. Nassar U, Hussein B, Oko A, Carey JP,Flores-Mir C. Dimensional accuracy of 2 irreversible hydrocolloid alternative impression materials with immediate and delayed pouring.Can Dent Assoc. 2012;78:c2.

18. Rodrigues SB, Augusto CR, Leitune VC, Samuel SM, Collares FM. Influence of delayed pouring on irreversible hydrocolloid properties. Braz Oral Res. 2012 Sep-0ct;26(5):404-9.

19. Kulkarni MM, Thombare RU. Dimensional changes of alginate dental impression materials-an invitro study. J Clin Diagn Res. 2015 Aug;9(8):ZC98ZC102. 
20. Demajo JK, Cassar V,Farrugia C, Millan-Sango D, Sammut C, Valdramidis $\mathrm{V}$, CamilleriJ. Effectiveness of disinfectants on antimicrobial and physical properties of dental impression materials. Int J Prosthodont 2016 JanFeb;29(1):63-7.
21. Ismail HA, Asfour H, Shikho SA. A self-disinfecting irreversible hydrocolloid impression material mixed with povidone iodine powder. Eur J Dent2016 Oct-Dec;10(4):507-11.

\section{Rafael Pino Vitti}

(Corresponding address)

University of Taubaté

Rua dos Operários 09, 12020-270

Taubaté, SP, Brazil

Date submitted: 2017 0ct 31

e-mail: rafapvitti@gmail.com

Accept submission: 2018 Jan 18 